Article

\title{
Globalization and Business Masculinities in South Korea: Top Managers in the Industrial Sector
}

\author{
Jaok Kwon \\ Centre for East Asian Studies, Heidelberg University, 69115 Heidelberg, Germany; \\ jaok.kwon@zo.uni-heidelberg.de
}

Received: 18 October 2019; Accepted: 16 November 2019; Published: 20 November 2019

\begin{abstract}
Along with the growing globalization of business, discussion concerning the "transnational business masculinity" has gained importance in recent years. Previous research on the transnational masculinity has argued for the convergence of business masculinity in a global level. This results partly from the fact that previous studies have concentrated largely on the West. Focusing on the Korean transnational corporations, this paper contributes theoretically by suggesting that the configuration process of business masculinity is neither linear nor straightforward towards convergence. Based on semi-structured, in-depth interviews with top managers in the industrial sector in South Korea (hereafter Korea), this paper clarifies that the construction process of the business masculinity is plural, multi-faceted, and divergent despite the emergence of convergence in combination with socioeconomic and political factors in the local, national, and global level.
\end{abstract}

Keywords: hegemonic business masculinities; industrial sector; globalization; Chaebol; South Korea

\section{Introduction}

Along with the growth of discussion on the transnational business class (Carroll 2010; Sklair 2001), greater attention has recently come to be paid to the relationship between globalization and the emergence of hegemonic business masculinity in a global arena. Due to the growing influence of neoliberal globalization, an understanding of extensive social processes and global relationships is necessary to grasp "masculinities on a world scale" (Connell 2005, p. xx-xxi). This is termed as "transnational business masculinity" (Connell 1998), which is defined as "the idea that global markets and transnational corporations provide the setting for a transformed pattern of business masculinity, which is achieving a hegemonic position in global gender relations" (Connell and Wood 2005, p. 362). The transnational paradigm of business masculinity is characterized by frequent global mobility, transnational social networks, job- and company-hopping, little attachment to the organization and nation, the importance of self-marketability and employability, and the maximization of profits and returns (Connell and Wood 2005). In particular, managerial masculinity in transnational business has played a significant role in the discussion of modern business masculinity, in the sense that men are predominantly the managers in company organizations (Collinson and Hearn 1996) and transnational corporations have gained hegemonic power "by the virtue of cultural, political and economic dominance of the institutions of multinational business" (Connell and Wood 2005, p. 362). This is especially the case when it comes to top managers, since the boardroom is mainly composed of men. Furthermore, an understanding of business masculinity among top managers is meaningful, since the ideology of top managers is supposed to be diffused, socialized, and internalized to each economic organization (Weber 1989). In this sense, the concept of transnational business masculinity is significant in order to obtain a better comprehension of the role of managers in the (re)construction and normalization of a gendered world order as well as the increasing power of a certain kind of masculinity as a "hegemony". As a result, transnational business masculinity has been positioned 
as a power to converge business masculinity in a global level, which is marked by a shift from the nation-state-based traditional bourgeois masculinity of a family-owned company to a global business elite of transnational corporations. Discussion around the transnational business masculinity is closely associated with convergence theory. Mainstream globalization and neo-liberal scholarship have both maintained that convergence among the managers on the global level has emerged by characterizing global economic elites in the transnational enterprises. This social group, who are named as a "transnational business class", is supposed to share commonalities in their possession of a strong educational background, individualized career path, performance-orientation, and transnational career mobility (e.g., Sklair 2001; Robinson and Harris 2000).

However, a question that we should address on the theoretical level is whether the configuration process of the transnational business masculinity is linear and straightforward towards convergence, as previous research has maintained. Based on semi-structured, in-depth interviews with top managers in the industrial sector in Korea, this paper clarifies the interactions of masculinities on the local, national, and global levels. First, this paper maintains the persistently gendered role within the family at the local level is rendered in a global arena through gender-segregated labor in a transnational household, thereby reinforcing the business masculinity. On the national level, not only the developmental state but also historical legacies and continuing geopolitical complexities have supported the construction of a business masculinity among chaebol-gigantic family-owned transnational corporations in Korea-as a hegemony. Finally, the "glocal" business identity, as a combination of loyalty to a "traditionalized modernity" and neo-liberalized management, has emerged as a hegemonic type of business masculinity. This business masculinity has been supported by growing "feminized" labor relations in a national level, as well as by a classified, racialized, and ethnicized labor market at a global level. By highlighting the case of Korea, which is one of the major non-Western economies, this research contributes theoretically to show that the configuration process of transnational business masculinity is neither linear and nor straightforward towards convergence. Despite the emergence of some signs for convergence, the construction process of the business masculinity rather consists of a plural, divergent, and multi-faceted interplay with the socioeconomic and political factors on the local, national, and global levels.

\section{Literature Review}

As Connell himself acknowledges, "transnational business masculinity is not completely homogenous" (Connell 1998, p. 17) across the global level. Masculinity is not monolithic, but it is rather multi-layered and plural, since masculinity is shaped by the particular circumstances in which men are positioned (Connell and Messerschmidt 2005). Therefore, a further broader and detailed investigation on how business masculinity has been constructed in the local as well as national levels, and how it develops in a global arena, is necessary. In particular, in the Asian context, even though there has been a significant effort to clarify the characteristics of salarymen as markers of hegemonic masculinity in Japan (e.g., Dasgupta 2003; Hidaka 2010), little attention has been paid to the intersections between salarymen masculinity and transnational business masculinity. More importantly, business masculinity in Asia such as Korea, China and India, despite their increasing economic power and global influences (Gray and Murphy 2013), has been marginalized in the discussion of transnational business masculinity. Despite the changing and diversifying world order in the global market, research to date on transnational cohesion among the transnational corporate elite has mainly focused on Europe and North America (Cárdenas 2015). In this context, analysis on modern men and business masculinities has met with the criticism that the current paradigm of business masculinity is closely associated with white imperialism, by merely focusing on "North" economies (Whitehead 2002). As a result, it is not still clear to what extent the transnational business masculinity could be positioned as a hegemony through its interplay with "Other" business masculinities in non-western economies, and in what ways this generates a certain type of business masculinity as a hegemony in a global arena. This is also related to the criticism of the transnational business masculinity by (Elias and Beasley 2009), which argues that while "it is 
important to look at global processes/structures and reveal how they are gendered (or more specifically masculinized), it is also necessary to investigate the relationship between the local and the global and to think through how everyday practices and relationships are reconfigured (or not)" (p. 291).

In analyzing the business masculinity in non-Western economies—with the case study of Korea in particular in this research-this paper maintains that the following factors should be taken into account. First, it is necessary to take the role of the family seriously into account in one's discussion. In the discussion of business masculinity, there have been some endeavors to pay attention to the role of family in recent years. In the Asian context, needless to say, family has been one of the major elements in the construction of business masculinity (e.g., Dasgupta 2003; Kim-Yi 2003). It is a well-known fact that the welfare system in Asia, which has heavily depended on family members (mainly women), has provided a strong impetus for rapid economic development. Nonetheless, despite recent attempts to shed light on the role of family in the construction of business masculinity (e.g., Hearn et al. 2017), the discussion on how the gender order within the family at the local, national and global levels has been interwoven into the formation of business masculinity has been little researched.

Next, developmental states in Asia are characterized by a strong state as a facilitator as well as a guidance for their economic development (Deyo 1987; Johnson 1982; Wade 1990). Korea has been positioned as one of them (Amsden 1989). Developmental states in Asia have constituted a very important element in the creation of global capitalism (Elias and Beasley 2009, p. 292). Furthermore, developmental states have played a pivotal role in the formation of a gendered order in the nation-state-building process in Asian economies (Elias 2008). In fact, the developmental state is still a very significant factor which should be considered in the analysis of the configuration of business masculinity in Asia, contrary to the broadly accepted perception of the collapse of the nation-state boundary in discussion concerning transnational business masculinity. Even though some scholars have pointed out that the ideology of the Korean business elite as a hegemony had been legitimized by the developmental state, based on historical perspectives (e.g., Kim and Park 2003), further analysis on how the historical legacy of the developmental state, as well as the post-developmental states in Korea, interact with the construction of the transnational business elite is necessary.

Finally, transnational business masculinity lacks the view on the intersections of race, ethnicity, nationality, and social class on the global arena. Since frequent global mobility means not only literally cross-border mobility but also cross-ethnic, cross-racial and cross-class encounters with different social groups, these points of view should also be taken into account. As (Suzuki 2007, p. 428) points out, "globalization has indeed differentially subjected men and various forms of masculinity along racial, ethnic, class, sexual, and national lines". Therefore, the question of how transnational business masculinity strengthens its hegemony in the cross-ethnic, cross-racial and cross-class boundary in a global arena deserves to be explored in a much more systematic way.

With regard to hegemonic masculinity in Korea, discussions have been had, in particular, on militarized masculinities in various contexts, such as the nation-state building process of the Korean Peninsula (Moon 2005a), the military conscription system (Moon 2005b), and military unionism (Kwon 2005). Even though there have been some meaningful endeavors to clarify business masculinity in Korea (e.g., Kim and Park 2003; Lee and Parpart 2018; Song 2003), the literature still lacks the agency of the top managers, inasmuch as researchers have been limited to analyzing autobiographies, company advertisements, and corporate social responsibility reports. In this research, we attempt to reveal the managers' agencies through their real voices and to explore how they have modified, challenged, and negotiated with the construction of business masculinity at local, national and global levels. Next, the literature on business masculinity in Korea has focused on the role of the bourgeois business capitalist class who emerged from out of the colonial period. This research might offer a further detailed understanding of how the ideologies of the bourgeois capitalist class has been shared, incarnated, and internalized to the professional managers, namely the next generation. Through this aspect, historical trajectories and dynamics of hegemonic masculinity (Connell 1998), and out of this the changes in and resilience of business masculinity, will be further explored. 


\section{Methodology}

The following discussion is based upon semi-structured, in-depth interviews with nine high ranking managers in the Korean industrial sector, which were conducted in 2012. Most (88\%) of the interviewees are one of the large family-owned Chaebols as well as transnational corporations such as Samsung, Hyundai, LG, SK, and Poongsan. $78 \%$ of the interviewees were top managers such as chairmen, presidents, or CEOs, and the remaining $22 \%$ of the interviewees were senior managers who belong to the boardroom, such as in the position of vice-president and CFO. In order to scrutinize the historical trajectories-marking continuities and discontinuities of business masculinity among the top managers-we separated the interview group by age cohort: the older generation, who were born before $1955(56 \%)$, and the younger generation (44\%), who were born after 1955. 1955 is the year marked which in Korea indicates the birth of the baby boom generation (1955-1963) after the Korean War (1950-1953). The mean age of the interviewed managers is relatively high, since the average job tenure for top managers is long because of the insider career system in Korea (Kwon et al. 2019).

The reason that we focus on the industrial sector in Korea in examining the business masculinity is that the manufacturing sector has so far been the largest pillar in supporting industrialization in Korea. In fact, "Korea has the largest share of manufacturing in GDP among OECD member countries and second largest share in the world after China" (Park 2016, p. 72). Even though the service sector has been the largest sector in the whole economy, the share of the industrial sector has constantly been the second largest sector in GDP in the Korean economy. Furthermore, the contribution of the manufacturing sector to Korean economic growth has been higher than the share itself since the 1980s until today. For instance, the contribution of manufacturing to economic growth reached an average of $43.9 \%$ by 2014.

We adapted semi-structured, in-depth interviews, since this interview form is appropriate for explanatory research (Redding 1990). This method enables the combination of the structured questions and the free spaces in elaborating the answers to the questions for the interviewees. The interviews were conducted with three structures within a research project on top managers in East Asia: Management, leadership, and work-life balance. The average interview duration was about from one and half to two hours. Out of the whole interviews, this paper mainly analyses the work-life balance part. All interviews were conducted in a face-to-face setting in the offices. All of the interviewees were native Koreans. Seven interviews were conducted in Korean. Two interviews were in English, in case a non-native Korean speaker participated in the interview as one of the interviewees and the interviewees were willing to perform the interview in English. All of the interviews were recorded under the consensus with the interviewees and each interview was transcribed for the analysis.

The data was analyzed with the MAXQDA program, which is the data analysis method for quantitative as well as qualitative data, or mixed forms of data. The interview data was classified according to topics relevant to the research question of this paper, such as work-life balance, family, relation to the state, working and living in a global environment, and transnational mobility. Even though our interview samples are very small (being only 9 in number), classification of the data was necessary. This is based upon the fact that the volume of the interview was large due to the long duration required for each interview, and the interviewees were allowed to narrate with considerable flexibility and freedom despite the semi-structured questionnaires. As the next step, every relevant interview clip was further analyzed in detail. The fact that the interview was conducted in Korean and analyzed by a Korean native speaker strengthened not only the quality of the interview but also the analysis itself, since the nuances as well as historical and socioeconomic background that each word has could be sophisticatedly reflected to the analysis. This is also the case for the interviewees who conducted the interview in English. Although the interviewees were not necessarily English native speakers, the sense of the language could be better understood and analyzed by the Korean native speaker. 


\section{The Interactions of Business Masculinities on the Local, National, and Global Levels}

\subsection{The Gendered Segregation of Labor within Family is Going Global}

"I worked almost $24 \mathrm{~h}$ a day. No holidays for decades. Therefore, it was very natural that I had no time to spend with my family. In the earlier stage of [the] industrialization process, there was a shared consensus among the general public that the economic development should come first. My family understood that I had to work not only for the family, but also for the nation." 1

"For the earlier industrialization process, it was a "take-for-granted" social norm that employees work all day long. My wife and children understood that I had to be absent at home. I have [n]ever participated in either the ceremony for entering school or [the] graduation ceremony of my two children from the elementary school to the university. My wife took care of all kinds of house-related stuffs."2

These two interviews with managers from an older age cohort clearly indicate the clear segregation between private/female and public/male spheres. Furthermore, the males' economic activities in the public sphere were prioritized as a national agenda which is associated with "a defense against the communist north, a solution to poverty and a strengthening of sovereignty" (Kim and Park 2003, p. 41). This form of reasoning legitimizes the absence of the father from the wider family unit and further strengthens the paradigm of business masculinity as a hegemony within the family. In this context, the family is described as a black box, in which there exists no conflicts, unequal power relations and negotiations. Moreover, the male-centered business masculinity was strongly promoted by the gendered nature of the developmental state with regard to family relations. The masculine developmental state regulated in this way a highly gendered social norm: "the modernization of gender hierarchy in industrializing South Korea during the period from the 1960s to the 1980s hinges on the construction and maintenance of femininity and masculinity, tied to the ideology of housewife and husband-provider and the gender division of labor" (Moon 2005a, p. 66). Under these socioeconomic circumstances, women were expected to conform to a role of being docile, supportive and subordinate subjects (Kim 2001). As the hegemonic masculinity of Japanese salarymen has been firmly supported by women's roles as mothers, wives, household managers, and caregivers in making up the country's family-centered welfare system, so called "familialism" (Esping-Andersen 1999), male workers' masculinities in Korea have also extensively relied on the support from the gendered segregation of labor at the household level (Kim-Yi 2003).

Also, long working hours have represented a major part of the business masculinity in Korea. In particular, the world of top business managers is characterized by long working hours as an indispensable part of the hegemonic business masculinity (Reid et al. 2018). Moreover, in Asian countries, where long working hours in general are familiar because of late capitalism and corporate institutional practices, the custom of long working hours has been legitimized as a tool to justify the marginalization of female work force in the managers' world (Nemoto 2016). For instance, in the survey in 2017, Korea was ranked in third place among those countries, where the working hours are longest with 2024 hours per year, while the average working hours in the OECD countries were 1759 hours (Leach 2018). Even though it is very clear that business masculinity as symbolized by long working hours is only possible with the entire support from the gendered nature of the family and household, it was viewed as a "standard norm" by the Korean managers.

With the globalizing economy, not only long working hours but also frequent global mobility seems to be a crucial part of business masculinity. Frequent global mobility has been pointed out

\footnotetext{
Interviewed on 19 October 2012 with a CEO, born in 1941.

Interviewed on 16 October 2012 with a CEO, born in 1947.
} 
as one of the features of transnational business masculinity. One top manager described the extent of his global mobility as follows: "I think that I have ever visited every single country in the world, beside socialist countries where I am not allowed to visit as a South Korean." 3 Not only temporary transnational mobility but also the prospect of long-term settlement for international assignments have also increased. (Kwon and Pohlmann 2018) proved empirically the increasing importance of international working experience through a quantitative study of the career patterns of top managers in industrial sector in Korea. This is not surprising when considering that industrial sectors of Korea has begun to broaden its management on a global scale, having begun to transfer production sites abroad and to explore international markets as a new frontier since the 1980s (Chang 2008).

"My wife and my son live in Tokyo. We see around once a month. If I go to Tokyo, I see my family and visit my customers."4

"In my case, work-life balance is much easier for me, because my family lives in the USA. My daughter just graduated from Stanford University and my son is going to Stanford. We have lived separately from 14 years ago. I go to the States twice a month. I travel a lot. I spend a lot of time, maybe 50 days per year, on the airplane. When I am in Korea, I can $100 \%$ concentrate on my work. I visit my kids on the weekends and spend time with them. My wife is working as a lawyer there, but she takes care of everything with regard to child rearing. However, I make my decisions for important agendas, you know, such as children's education and career. So, the balance between my work and private life is quite well managed." 5

From these two interviews from younger age cohort, we were able to glimpse the persistent segregated gender roles in the transnational parenting and household management, aside from the growing economic participation of the spouse and globalized spatial mobility. Furthermore, the paternalistic role in the family relationships are well represented, since this interviewee speaks as if the family should be under control and management of the male head. This way of thinking follows the same lines as those of an interview with one of the older age cohort:

"Even though we hear about work-life balance more often in these days, I believe that long working hours for top managers will not eventually be changed. The thing is not how long you spend your time with your family, but how you spend the time effectively with them. Not only the efficiency of working time, but also the time with family should also be managed in a productive way." 6

(Park 2018) has clarified the sharp gender disparity in the parenting roles of the Korean family from a high society in a transnational context. Particularly noticeable is the mothers' lifelong care for and management of children's private lives and the fathers' growing involvement in their higher education and career. Interestingly, children's narratives reflect the reproduction of gender norms in the parenting, in the sense that they consider mothers' lifelong involvement in everyday life as a less valued and unchallenging one, while the fathers' occasional yet determinant involvement in the major decision-making in education and career is viewed as a highly valued one.

Furthermore, the mindset to "put work first" (Reid et al. 2018, p. 589) is clearly demonstrated in these abovementioned two interviews, when considering that the visit of the family is assumed to be a part of a business trip in the first interview, and the emotional burden by partners under the global arena is silenced in both interviews. Even though there have been some efforts to shed light on

Interviewed on 15 October 2012 with a CEO, born in 1946.

Interviewed on 12 October 2012 with a vice-president, born in 1960.

Interviewed on 23 July 2012 with a CEO, born in 1958.

Interviewed on 19 October 2012 with a CEO, born in 1941. 
the trailing spouses, as we could observe in the management studies on global managerial expats, women's issues have been little discussed. This is because the power of dominant masculinities could be maintained by overlooking the existence of points of view that could negatively influence existing power relations (Connell 1995).

(Kurotani 2005) further portrays how expats' housewives, who are abruptly required to settle in foreign countries because of their husbands' increasing international assignments along with the broader globalization of business environments, often struggle with their everyday lives in foreign countries when it comes to the transnational boundaries of language, ethnicity, culture, race, and the constructed image of the sexuality of "Asian women" in the host country. On the one hand, they are expected to domesticate their global lifestyle by homemaking away from home, so that the male breadwinners could maximize their work productivities in a given time under atypical social environments in work and life. At the same time, trailing wives should manage the "emotional burdens of the mothers which derive from their increasing engagement in intensive mothering and identity management in a transnational social field" (Nukaga 2012, p. 66). In particular, as indicated from the aforementioned interviews, the families of Korean managers, like other East Asian middle-class families, are more interested in staying abroad for longer in order to provide a better education for their children as a means of achieving upward mobility for the family, even when the assignments of husbands are complete (Yeoh et al. 2005). These cases demonstrate that "transnational business masculinity" still enjoys interplay with the local gender norms_-"fatherless households" (Taga 2005, pp. 132-33)—which are embedded within the nation-state-based cultural and institutional norms. At the same time, the global mobility and frequent dislocation of top managers all help to construct, reconstruct and strengthen the gender division of labor within households in a global arena.

\subsection{Business Masculinity: Industrial Warriors with Nationalist Sentiments}

"In the 1950s, South Korea was one of the poorest countries in the world. Our parents taught us only one thing: education is the sole way to build a nation. We worked really hard to enter a good university and I entered the Seoul National University. As I graduated from the university, that was the time when President Park Chung Hee (1962-1979) tried to transform the industrial structure from light industry to heavy- and chemical industry. But we had no enterprises which were capable of leading such a big business. President Park himself selected 10 big enterprises and sent some business elites of the companies to Japan to learn the know-hows and skills. That was the start of the industrialization in Korea. And we are the first generation who participated in the industrialization process." 7

From the interviews above, a spirit of "we" is discernible underneath, which is not explained by the interviewees but as something shared together as a "take-for-granted". First, this "we" spirit refers to the continuing importance and power of industrial sector in emerging economies including Korea. (Roper 1991) sheds light on the displacement and power shift from a production-oriented masculinity in the industrial sector to the managers equipped with financial orientation. Furthermore, along with the rise of liberalization of the financial markets, it has been maintained that masculinities in the financial sector have gained prominence with regard to their hegemonic capacity (Knyght et al. 2011). Therefore, in the discussion of transnational business masculinity, masculinities in the financial sector have been considered as a hegemony on the global level (Connell 2005). However, our findings once more emphasize the fact that more attention should be paid to the plurality of the hegemonic masculinities (Connell 1998) in various capitalist systems, since the business sector in a nation-state might have a great influence in creating and legitimizing a hegemonic masculinity in a society through its interplay with the historic relations of economic and political domination (e.g., Elias 2008). By comparing

7 Interviewed on 15 October 2012 with a CEO, born in 1946, italic by author. 
major industrialized economies which have shifted from an industrial structure in manufacturing to service and the financial sector, such as Great Britain (9.7\%), France (11.3\%), and the USA (12.1\%), it is important to note that the industrial sector is still important, especially for emerging economies such as China (29.9\%) and Korea (31.3\%) (Ministry of Trade, Industry and Economy 2015, p. 30).

In fact, business masculinities in the industrial sector in Korea as a hegemonic masculinity have a significant meaning in the formation of hegemonic masculinity in Korea. "Industrial warriors", who were mainly the blue and white workers of heavy and chemical industries, have created an intensely militaristic "on-the-job" training culture from the 1960s through to the 1980s (Moon 2005a). This has presumably influenced not only the manufacturing sector, but also other business sectors up to the present day. For instance, one of the major banks in Korea was severely criticized, since it was publicized that the company provided oral contraception pills to the newly hired female employees to control their menstrual cycles before a 100-kilometer overnight militaristic march as part of the on-the-job training, a decision which was defended as a "tradition" to the rookies to boost their morale (Park 2018, 9 January). This indicates the continuation and prevalence of deep-seated military masculinity as a hegemony through militarism, collectivism, and the denial of feminine body, which has been implicitly and explicitly accumulated in (especially) the manufacturing sector in large enterprises. Furthermore, the phenomenon of militaristic unionism (Lee 2011), which has developed out of the manufacturing sector of large Chaebol, has marginalized the participation of female workers in the union activities by endorsing feelings of denial towards the female body as unsuitable to the militaristic unionism (Kwon 2005).

Furthermore, one can refer to the male-centered nature of discourses surrounding economic achievements and contribution in Korea. In other words, the "we" refers to the industrial warriors of Chaebol in the male-dominant, heavy- and chemical manufacturing industries (Kim 2013), which have played a significant role in economic development since the 1970s, rather than to the female-dominant light manufacturing industries in the small- and medium sized enterprises. In fact, the labor force by young female workers was an important resource for the developmental state in the earlier stages of industrialization. The 1960s and 1970s were the period when the economic participation rate of the female labor force increased with the most rapid speed in modern Korean history, jumping from $26.8 \%$ in 1960 to $45.7 \%$ in 1975 . In particular, the participation rate of the young female labor force aged between 15 and 24 years old was very high, making up 40-50\% during this period (Jang 2001). These young female workers were mainly concentrated in underpaid light manufacturing industries under relentless working conditions. Until 1975, 70\% of the total amount of exports came from the female-dominant light manufacturing industry (Kim 2001, p. 57). Young female workers in the light industries were also named industrial warriors, yet they were either used in the context of maximizing productivity in an asexualized way (Lee 2003) or they were closely associated with "productive femininities" (Elias 2008, p. 410) in such a way as to further strengthen the hegemonic masculinity of male managers. These are the results from the developmental state's gender segregated labor market strategies-"nimble fingers" for female workers and "masculinization of skilled labor job training in the heavy and chemical industries" (Moon 2005a, p. 58). Furthermore, the Chaebol enterprises restricted the engagement of the female labor force from the entry level, by obligating the completion of military service as a precondition for a job application until the enforcement of Equal Employment Law (1988) (ibid, p. 39).

(Koo 2001) points out that the economic contribution by female workers in the manufacturing sector in the industrialization process has been less appreciated. The following interview with a top manager from a younger age cohort well reflects the persistently deep-rooted "otherization" of females in the industrial sector. 
"Female managers are extremely rare in our sector. I think that there are sectors, in which females might present their capabilities in a better way. I suppose that advertisement or fashion industries might be their world." 8

This interviewee expresses the attitude towards the gendered employment segregation in the industrial sector as a self-evidently natural one through its "otherizing" of female managers. Additionally, it implicitly marginalizes other female-dominant sectors as being of less worth in Korea's economic development. According to the Ministry of Gender Equality and Family, in a survey based upon the sales turnover in 2017 in Korea, the share of female board directorates was 3\% in the whole board members out of the top 500 enterprises. Out of the top 500 companies, $65.6 \%$ of the companies had no female board directorates. When considering that the mean share of the female board directors of the OECD (Organization for Economic Co-operation and Development) countries is 21.8\% in 2018, the share of the female board directorates in Korea is extremely low. Out of the top 500 companies, even though over half (50.4\%) of the companies were from the industrial sector (including construction), the share of the enterprises with more than one female board directorates in the industrial sector was the lowest, at only 23.1\% (Ministry of Gender Equality and Family 2018). The next interview also clearly indicates the marginalization of women within a "team".

"Our company has a mentor system. As a top manager, I try to manage my team from the work to the personal life. For instance, on the weekends, we clime up the mountain, play football with them, and go to sauna together after drinking." 9

In industrial relations studies, male workers have been regarded as the "unrecognized norm"-in other words, as a standard worker. Even though they have never been named as "men", they have always stood in the center of the discussion as "workers", "citizens", and "unionists". In this circumstance, male workers became the "unrecognized norm" (Pocock 1997, p. 6) in the male dominant labor market, while women's "nature", body and sexuality have been called into question and positioned as women's issues or femininity, which is deviant from the "standard norm". In this sense, (Mac an Ghaill and Haywood 2007) maintain the importance of studying men and masculinity in gender studies, which challenges the conventional perspective of only marking women as gendered beings. They argue that "analyzing men as a politically gendered category removes it from its normative location as transparent, neutral and disembodied" (ibid, p. 29).

Additionally, "we" means the employers of Chaebol as well as the identity for the nation itself. The business masculinity of top managers-as hard working, diligence, courage, and challenging spirits-, in particular for the older generation, is closely associated not with self-achievement, self-development and the marketability of oneself, but rather with nationalistic sentiments. The close relationship between the state and the Chaebol has contributed to the legitimization of hegemony in the creation of the Chaebol masculinity. Under the Confucian parental governance in the 1960s and 1970s, the Korean developmental state used a hierarchical and gendered metaphor of familial relationships in regulating the state-society relations (Han and Ling 1998): the state as father, corporations as its sons, and the society as women-be it either wife or daughters who are in either case supposed to support the state and the corporations with cheap labor. In particular, Chaebol, as the first son of the state (changnam) could enjoy various beneficiaries in the earlier process of industrialization (Kim 2001). The close relationship between the state and Chaebol had been further strengthened during the conservative regimes-Lee Myung-bak (2008-2013) and Park Geun-hye (2013-2017). An interviewee, a 52-year-old young vice president of one of the family-owned Chaebol enterprises, clarifies this point as follows:

"As you know, since the President Lee Myung-bak in office, a lot of business friendly policies have been introduced. He himself was a CEO in the industrial sector in a Chaebol group.

8 Interviewed on 12 October 2012 with a vice president, born in 1960, italic by author.

9 Interviewed on 11 October 2012 with a senior manager, born in 1956. 
Therefore, he knows the mechanism and needs of enterprises really well. He knows well that Korea has no natural resources, therefore, export-oriented economic policies should come first for our nation." 10

Regardless of the age group considered, from the interviews above the gendered metaphor is clearly presented: The developmental state as a caring and nurturing father and the male-dominated Chaebol enterprises as a strong follower as well as a supporter of his father as a beloved first son. In this sense, the Chaebol masculinities have been legitimized as an example of hegemonic masculinity. Furthermore, the Chaebol masculinity has been further firmly stabilized after the Asian financial crisis and the following corporate reforms. The lack of transparency and accountability of Korean firms, in particular Chaebols, which had enjoyed the beneficiaries from the development state, were criticized as requiring the most urgent reform agenda right after the crisis at the earlier stage (Kim 2014, p. 163). However, the reform process and engagement of various transnational actors changed the hostile sentiments against Chaebol dramatically. Transnational actors, such as the IMF and global financial institutions who implemented reform programs and who were required to open the financial market, were depicted as global imperialists (Kim 2013) and were easily combined with discourses on xenophobic sentiments which exploits national competitiveness (Hayo 2005). The involvement of foreign speculators to the SK Corporation is one example, which overthrew the anti-Chaebol mood (Lim and Jang 2006). As a result, the "backlash against the rising share of foreign ownership enhanced the image of the Chaebol as national champions" (Ha and Lee 2007, p. 894). The discussion on the second rise of economic nationalism through the Asian financial crisis also further strengthened the salaryman masculinities, by associating the male breadwinners who lost their jobs with the company's restructuring (Kim and Finch 2002). In particular, the unemployment of male workers from large companies resonated as an urgent issue and was depicted as a collapse of the fundamental economic basis in Korea. Of course, "with income equality growing and social polarization deepening, the demand for a fairer re-distribution of wealth across society is now the 'Zeitgeist' in Korea" (Kim 2017). In these newer circumstances, corruption scandals coming from the close relations between business and the state, and the immoral misbehavior (gapjil) of the Chaebol have been strongly criticized in the current neoliberal era in Korea. This might lead to a weakening in the legitimacy of Chaebol masculinity as a national symbol supporting the whole Korean economy. Meanwhile, the historic legacies such as colonial memories, Western imperialism, postcolonial sensitivities, and the ongoing antagonistic geopolitical situation in East Asia could easily change the attitudes towards Chaebol as well as Chaebol masculinities from antipathy to sympathy. The joint work between the representative Chinese Huawei and Korean Chaebol LG has been described as a "loss of national pride" and "national shame" under the growing political tension triggered by the Chinese government's economic sanctions on Korea.

This last point is also well connected with the business masculinities in Japan, which has been "set against stereotypically nationalist representations of the foreign (American) Other" (Dasgupta 2013, p. 486). (Roberson 2005) also discusses the hegemonic business masculinities in Japanese energy health drinks, which describes the "white racialization of the foreign 'other'" by positioning the West as a global rival and business competitors (p. 379). The discussion in this section demonstrates the need for further consideration in the study of business masculinities in the relation to nation-state both in non-western economies and in emerging economies with their historical legacies such as colonialism, imperialism, and post-colonialism.

\subsection{The Chaebol-Centered Business Masculine Identity and a League of Their Own in a Global Arena}

As we discussed in the previous section, the development of greater nationalism and the emergence of Chaebol as a form of national identity has been certainly called into question. On the one hand, this is due to the spread of neo-liberal restructuring and the rise of social divides. On the other hand, as one

10 Interviewed on 12 October 2012 with a vice president, born in 1960. 
of the emerging economies with colonial memories, antipathy to imperialism, and post-colonialism, these issues has easily resonated through their interplay with the conception of Korea as a "nation" (Hirst and Thompson 2005). Meanwhile, apart from oscillation between sympathy and antipathy towards Chaebol and the role of the developmental state in positioning Chaebol as a national identity, it is very true that neo-liberal elements have been actively introduced into Chaebol enterprises as a general tendency. The next interview points out the growing importance of maximizing performance not only on the corporate level, but also on the individual level in the current era:

"The [majority] of the CEOs in the earlier industrialization process were founders. They share a same philosophy that Korean enterprises should achieve the rapid economic development for the nation, regardless [of] its different name of the company groups. In these days, it is different. It has been more individualistic. On the corporate level, every company group tries to create their own image. Furthermore, on the individual level, every single performance and skill of each individual will be reflected to the promotion."11

Since the Asian financial crisis, Chaebol has been especially active in the domain of labor market reform, having introduced a series of measures which mark an increase of performance-orientation, erosion of seniority system, and a competitive-based wage system (Koo 2007). However, this does not necessarily lead to the emergence of transnational business masculinity, which is characterized by little attachment and loyalty to the company organization. Rather, a hybrid form of "glocal" business masculinity-a traditional paradigm of patriarchal relations between employers and employees bound with long-term commitment and loyalty, as well as the strengthening of competitive elements-has been forged.

The generalized term "Samsung man" in Korea has been used since the early 1990s, when the Chairman of the second generation, Lee Gun-hee, attempted to reshape the image of the business group in a modern and globalized way. This is the very time when each Chaebol group attempted to create their own image-not as one of the local family-owned Korean enterprise, but as a globalized company in the global market. ${ }^{12}$ Most of the interviewees proudly identified themselves as an "organization man (Whyte 1959)" of each Chaebol group: "Samsung man", "Daewoo man", “Hyundai man", etc. The pride behind this form of self-identification seemed to come from the long-term commitment, lifelong loyalty, and passion which they devoted to the company as a core member of each group. The career patterns of top managers in Korea in the industrial sector also clearly demonstrates the importance of long-term commitment either to the company or the company group. (Kwon and Pohlmann 2018) suggest that $100 \%$ of the CEOs of the 100 top industrial companies in 2010 in Korea have built for themselves an in-house career, in contrast to the generalized wisdom among the transnational capitalist class with its features of job- and company-hoppers for the maximization of returns on investments of time and capital as well as the maximization of self-marketization (Arthur and Rousseau 1996). According to Kwon et al. (2019), interestingly, the ratio of the in-house career of top managers in Korea is even higher than that of Japan, which has been well-known for its longtime employment practices. The company-group-based identity is well illustrated in the next example:

"Samsung provides for the employees a lot of on-the-job training program. They try to mold them into a 'Samsung man'. As a 'Samsung man', we learn how we nurture loyalty to the company. It applies to every employee of Samsung." ${ }^{\prime 3}$

The so-called "Samsung Shared Value Program" has been well-known for its structure, regularity, and intensity. It is characterized by its economic compensation and corporate-based welfare system,

11 Interviewed on 27 July 2012 with a senior manager, born in 1950

12 For instance, "Samsung man", "Hyundai man", "Daewoo man" has started to be used in the major Korean newspapers since the early 1990s.

13 Interviewed on 26 July 2012 with a senior manager, born in 1946, italic by author. 
which aims to mold a "company man of a community firm" (Inagami and Whittaker 2005) with infinite commitment and devotion to the organization (Chang 2006, p. 33). The following interview indicates that Samsung's identity education as well as its welfare system has strongly influenced other Chaebol enterprises in a similar way.

"Samsung has certainly labor unions. However, employees do not think that they need any collective bargaining, since Samsung provides a full-package of fringe benefits, before the employees demand their rights. Hyundai has been famous for the militaristic labor unionism. However, it has been also changed. The Hyundai group has attempted to adopt the system of the Samsung's."14

However, even though this "glocal" company identity has been stressed for all employees, the number of employees who are actual beneficiaries has decreased since the Asian financial crisis in 1997. (Song 2014) explains that the liberalization of the labor market after the Asian financial crisis has led to the flexibilization and instability of the labor market in a general way, but not for the small number of core workers of Chaebol enterprises. Since then, the nation-wide trade union, which is composed of a core of male workers of Chaebol enterprises, have been criticized as representing a "collective egoism" (Kim 2005). Ironically, the company-based identity has been required not only for core workers but also for non-regular employees, who have been supporting the Chaebol system. Even though they are not directly hired from the Chaebol enterprises, these non-regular workers are a major element in supporting and strengthening the business masculinity of core workers as a hegemony in the Chaebol system as well as in the wider Korean society. (Lee and Parpart 2018) maintain that employees with an atypical employment contract-most of whom are women and whose number of male non-regular workers has been increasing-have been "utilized as the backdrop against which the masculinity of salarymen can be constructed and defined as a hegemonic norm" (p. 317), through the feminized form of labor contracts and the consequentially marginalized masculinity.

Moreover, the construction of a hegemonic business masculinity among the core workers, including managers, is supported not only by the growing number of non-regular employees, but also by the core versus periphery relations in the labor market on the global level. This has in turn been created by the globalization of Korean transnational corporations, in particular in Asia. The conventional wisdom of the "'dependence of Asia on the Western capital' has been dramatically transformed into the 'dependence of workers from developing economies in Asia on gigantic Asian capital'. Asian transnational capital has taken the initiatives in industrialization and globalization by integrating workers from developing countries to the global factory" (Chang 2008, p. 13). With regard to the characteristics of the labor union and welfare system for the core workers of Chaebol enterprises, (Chang 2009) has critically examined the segregation of the labor market in terms of gender and ethnicity: a small number of core workers are based in the headquarters in Korea and a majority of marginalized foreign workers are based in the production sites abroad who support the gigantic Korean transnational corporations. Not only non-regular contract workers in Korea but also foreign workers in the site are equally named as "Samsung man", "Hyundai man", or "LG man".

"We have factories in China. They have also labor unions. However, it is government-oriented unionism, which means that the relations between the enterprise and the workers are very harmonious. This is an ideal form of industrial relations." ${ }^{\prime 15}$

Since the 1980s, Korean transnational corporations have "relocated their labor-intensive production offshore to their poorer Asian neighbors" (Wang 2005, p. 43). In the above-mentioned interview, Chinese workers are rendered as being non-threatening to the industrial relations. Chinese workers'

14 Interviewed on 22 July 2012 with a senior manager, born in 1950.

15 Interviewed on 13 October 2012 with a senior manager, born in 1956, italic by author. 
"harmonious" industrial relations are positioned as a shared value through "self-Orientalism", on the one hand. On the other hand, the possibility of collective bargaining and unionism by Chinese workers are "otherized" as an "unideal" and "undesirable" norm. This logic also applies to the Korean-American employees.

"I hired Korean Americans with language proficiency as subordinates, since our business was international sales department. They work hard and diligently and they understood Korean organizational culture well. However, $99 \%$ of the enterprises in the industrial sector were against them, with the reason that they do not understand Korean organizational culture."16

In this interview, "diligence" and an "understanding of Korean organizational culture" are viewed as a shared "traditional" value as a major element of "Korean-ness". At the same time, the Korean workforce are in this case "otherized" by stressing the acceptance of "foreignness" of Korean-American employees as an exceptional case.

As we have discussed in this section, the Chaebol-based identity is a "glocal" business masculinity-a hybrid form of masculinity which combines "traditionalized modernity", such as paternalistic industrial relations with unconditional commitment and loyalty, and competition-based neo-liberalized career systems and practices. This Chaebol-based business masculinity of Korean transnational corporations has been supported by the increasingly feminized as well as the periphery-level labor relations both in Korea and abroad in the offshore market. Top managers themselves have played an important role in the (re)configuration of business masculinity through everyday practices across racial, ethnic, and national boundaries by creating "self-orientalism", while at the same time "otherizing" the different genders, employment relations, nationalities, and ethnicities as "foreign" and "marginalized" in comparison to the hegemonic business masculinity.

\section{Discussion}

Based upon semi-structured, in-depth interviews, this paper argues, firstly, how the family in the local, national, and global arena has been the main pillar that has firmly supported the business masculinities of top managers of the largest enterprises. Next, the developmental state has been a major supporter in the construction of the business masculinity of male workers among the Korean transnational corporations. Furthermore, national boundaries still constitute a major element in the positioning of business masculinity as a hegemony which interrelates with historical legacies such as colonial memory, imperialism, and the ongoing geopolitical situation in the East Asian context. Finally, the "glocal" business identity, which consists in an emphatic loyalty as a "traditionalized modernity" and the active adaptation of neo-liberalized career system, has emerged as a hegemonic business masculinity. This business masculinity has been strongly supported not only by growing feminized labor relations and a marginalized masculinity at the national level, but also by classified, racialized, and ethnicized labor relations. The enlargement of Asian transnational corporations has legitimized the hegemony of business masculinity through the sharing of "Asianness/self-Orientalism" as well as "foreignness/Otherization" in Asia.

On the empirical level, the most significant contribution of this research is that it attempted to illustrate the managers' agencies through interviews with them. Through their real voices, we could better understand how they have dealt with and positioned themselves in the construction of business masculinity at local, national and global levels. Furthermore, it was also meaningful that this research highlighted the business masculinity of the professional managers in Korea. Even though the previous research has partly discussed the business masculinity of the founders of the big enterprises by analyzing their autobiographies, company advertisement and media interviews, the understanding on how the ideology of the bourgeois capitalist class has been shared, incarnated, and internalized

16 Interviewed on 22 July 2012 with a senior manager, born in 1950. 
to the professional managers has been lacking. In this sense, this paper has contributed to the better understanding on the changes in and resilience of business masculinity in Korea.

On the theoretical level, this paper attempted to examine whether a transnational business masculinity has converged in non-Western economies by analyzing the hegemonic masculinities of top managers in the industrial sector of gigantic transnational corporations in Korea. The theoretical contribution of this research is twofold. First, this paper indicates that the developments of transnational business masculinity do not travel in a straightforwardly linear path towards convergence but are rather multi-directional and uneven. This result indicates that discussion concerning the transnational business masculinity should be closely associated with a range of institutional factors, such as family, enterprises, and the state. In this sense, a deeper understanding of the divergent form of the capitalist system (e.g., Hall and Soskice 2001) and its interrelationship with the construction of transnational business masculinity is necessary. Second, regarding the first point, although convergence pressures affect various countries to different extents, changes are path-dependent by nature in each country, according to the existent institutions (e.g., Mahoney 2000; Pierson 2000). As we could see with the construction process of business masculinity in Korea, it has been influenced by the strong streams towards convergence. However, it has also continuously been in interplay with elements on both the local and national levels, such as the gendered order, the historical legacy, the sociopolitical tensions in an East Asian context, and the interrelations between the enterprises and the (post)developmental state. This demonstrates that discussion concerning the transnational business masculinity should take the different institutional settings of the diverse capitalist systems more seriously into account.

I must note some limitations of this paper. Even though this paper focused on business masculinity in the industrial sector as a representative area of the Korean economy, an analysis which is cross-sectoral as well as cross-positional (encompassing not only top managers, but also middle manager positions) will provide a broader understanding of the dynamic picture of changes to and resilience of business masculinity in Korea. Second, it should be noted that this analysis could be limited in terms of its generalization because of the small sample size. Finally, despite the attempts to clarify the interrelations of the business masculinity on the local, national and global levels in this paper, a further examination of how business masculinity in Korea, as a non-Western economy, interacts with other forms of business masculinities in the global setting, is necessary.

Funding: This work is supported by the Academy of Korean Studies Research Grant (AKS-2016-02), German Research Association (PO585-9/1) and the Cluster of Excellent Asia and Europe in a Global Context (A26). I also acknowledge financial support by Deutsche Forschungsgemeinschaft within the funding programme Open Access Publishing, by the Baden-Württemberg Ministry of Science, Research and the Arts and by Ruprecht-Karls-Universität Heidelberg.

Acknowledgments: I thank Markus Pohlmann who gave me the permission to use the interview data for this manuscript. I also thank two reviewers for their constructive and insightful comments.

Conflicts of Interest: Author declares no conflicts of interest.

\section{References}

Amsden, Alice H. 1989. Asia's Next Giant: South Korea and Late Industrialization. New York: Oxford University Press.

Arthur, Michael B., and Denise M. Rousseau, eds. 1996. The Boundaryless Career: A New Employment Principle for a New Organizational Era. Oxford: Oxford University Press.

Cárdenas, Julián. 2015. Are Latin America's corporate elites transnationally interconnected? A network analysis of interlocking directorates. Global Networks 15: 424-45. [CrossRef]

Carroll, William K. 2010. The Making of a Transnational Capitalist Class: Corporate Power in the 21st Century. London: Zed.

Chang, Dae-oup. 2006. Samsung. In Labour in Globalising Asian Corporations: A Portrait of Struggle. Edited by Dae-oup Chang. Hong Kong: Asia Monitor Resource Centre, pp. 3-178.

Chang, Dae-oup. 2008. Introduction. In Ashiaro kan Samsŏng (Samsung Going to Asia). Edited by Dae-oup Chang. Seoul: Humanitas, pp. 12-20. 
Chang, Dae-oup. 2009. Informalising labour in Asia's global factory. Journal of Contemporary Asia 39: 161-79. [CrossRef]

Collinson, David L., and Jeff Hearn, eds. 1996. Men as Managers, Managers as Men: Critical Perspectives on Men, Masculinities and Managements. London: Sage.

Connell, Robert. W. 1995. Masculinities. Berkeley: University of California Press.

Connell, Robert. W. 1998. Masculinities and globalization. Men and Masculinities 1: 3-23. [CrossRef]

Connell, Robert. W. 2005. Masculinities, 2nd ed. Sydney: Allen and Unwin.

Connell, Robert. W., and James W. Messerschmidt. 2005. Hegemonic masculinity: Rethinking the concept. Gender $\mathcal{E}$ Society 19: 829-59. [CrossRef]

Connell, Raewyn W., and Julian Wood. 2005. Globalization and business masculinities. Men and Masculinities 7: 347-64. [CrossRef]

Dasgupta, Romit. 2003. Creating corporate warriors: The "salaryman" and masculinity in Japan. In Asian Masculinities: The Meaning and Practice of Manhood in China and Japan. Edited by Louie Kam and Morris Low. London: RoutledgeCurzon, pp. 118-34.

Dasgupta, Romit. 2013. Re-Reading the Salaryman in Japan: Crafting Masculinities. Abingdon: Routledge.

Deyo, Frederic C., ed. 1987. The Political Economy of the New Asian Industrialism. Ithaca: Cornell University Press.

Elias, Juanita. 2008. Hegemonic masculinities, the multinational corporation, and the developmental state: Constructing gender in "progressive" firms. Men and Masculinities 10: 405-21. [CrossRef]

Elias, Juanita, and Christine Beasley. 2009. Hegemonic masculinity and globalization: 'Transnational business masculinity' and beyond. Globalizations 6: 281-96. [CrossRef]

Esping-Andersen, Gosta. 1999. Social Foundations of Postindustrial Economies. Oxford: Oxford University Press.

Gray, Kevin, and Craig N. Murphy. 2013. Introduction: Rising powers and the future of global governance. Third World Quarterly 34: 183-93. [CrossRef]

Ha, Yong-Chool, and Wang Hwi Lee. 2007. The politics of economic reform in South Korea: Crony capitalism after ten years. Asian Survey 47: 894-914. [CrossRef]

Hall, Peter A., and David Soskice, eds. 2001. Varieties of Capitalism: The Institutional Foundations of Comparative Advantage. Oxford: Oxford University Press.

Han, Jongwoo, and Lily HM Ling. 1998. Authoritarianism in the hypermasculinized state: Hybridity, patriarchy, and capitalism in Korea. International Studies Quarterly 42: 53-78. [CrossRef]

Hayo, Bernd. 2005. Mass attitudes toward financial crisis and economic reform in Korea. Socio-Economic Review 3: 491-515. [CrossRef]

Hearn, Jeff, Marjut Jyrkinen, Mira Karjalainen, Charlotta Niemistö, and Rebecca Piekkari. 2017. Top men in transnational companies: The construction of men, masculinities, and work-family intersections within "gender-neutral" contexts. In Gender in Transnational Knowledge Work. Edited by Helen Peterson. Cham: Springer, pp. 99-118. [CrossRef]

Hidaka, Tomoko. 2010. Salaryman Masculinity: The Continuity and Change in Hegemonic Masculinity in Japan. Leiden: Brill Academic Publishing.

Hirst, Paul, and Grahame Thompson. 2005. Globalization in Question, 2nd ed. Cambridge: Polity Press.

Inagami, Takeshi, and D. Hugh Whittaker. 2005. The New Community Firm: Employment, Governance and Management Reform in Japan. Cambridge: Cambridge University Press.

Jang, Mikyung. 2001. Kŭlloyŏsŏng 50nyŏnsa ŭi chŏngni wa p'yŏngga (Fifty years of history of working women). In 21segi Kŭlloyŏsŏngjŏngch'aek ŭi Kibonbanghyang e Kwanhan T'oronhoe (Discussion on the Future Politics on the Working Women in Korea); Edited by Korean Women's Development Institute. Seoul: Ministry of Employment and Labor, pp. 75-125.

Johnson, Chalmers. 1982. MITI and the Japanese Miracle. Stanford: Stanford University Press.

Kim, Andrew Eungi, and Gil-sung Park. 2003. Nationalism, Confucianism, work ethic and industrialization in South Korea. Journal of Contemporary Asia 33: 37-49. [CrossRef]

Kim, Hyung-A. 2013. Industrial warriors: South Korea's first generation of industrial workers in post-developmental Korea. Asian Studies Review 37: 577-95. [CrossRef]

Kim, Hyun Mee. 2001. Work, nation and hypermasculinity: The 'woman' question in the economic miracle and crisis in South Korea. Inter-Asia Cultural Studies 2: 53-68. [CrossRef]

Kim, Joongi. 2014. Corporate governance reform in Korea in the post-Asian financial crisis era. In A Comparative Study of East Asian Capitalism. Edited by Hong Yung Lee. Berkeley: University of California Press, pp. 161-84. 
Kim, Seung-Kyung, and John Finch. 2002. Confucian patriarchy reexamined: Korean families and the IMF economic crisis. The Good Society 11: 43-49. [CrossRef]

Kim, Sunyoung. 2005. Pijŏnggyunodongshijangŭi chendŏgujo: Hanilbigyorŭl chungshimŭro (Gender structure in non-regular labor market: A comparative studies of Korea and Japan). Yeoseongkwa Sahoe (Women and Society) 16: 103-36.

Kim, Youngmi. 2017. Hell Joseon: Polarization and social contention in a neo-liberal age. In Korea's Quest for Economic Democratization: Globalization, Polarization and Contention. Edited by Youngmi Kim. Cham: Palgrave Macmillan, pp. 1-20.

Kim-Yi, Eunhee. 2003. Home is a place to rest: Construction the meaning of work, family and gender in the Korean middle class. In Korea Anthropology: Contemporary Culture in Flux. Edited by Korean National Commission for UNESCO. Seoul: Hollym.

Knyght, Reeves, Nada Kakabadse, Andrew Kakabadse, and Aleander Kouzmin. 2011. When rules and principles are not enough: Insiders' views and narratives on the global financial crisis. Journal of Change Management 11: 45-67. [CrossRef]

Koo, Hagen. 2001. Korean Workers: The Culture and Politics of Class Formation. Ithaca: Cornell University Press.

Koo, Hagen. 2007. The changing faces of inequality in South Korea in the age of globalization. Korean Studies 31: 1-18. [CrossRef]

Kurotani, Sawa. 2005. Home Away from Home: Japanese Corporate Wives in the United States. Durham: Duke University Press.

Kwon, In-Sook. 2005. How identities and movement cultures became deeply saturated with militarism: Lessons from the pro-democracy movement of South Korea. Asian Journal of Women's Studies 11: 7-40. [CrossRef]

Kwon, Jaok, and Markus Pohlmann. 2018. Globalization and corporate elites in South Korea: education and career mobility. Korea Observer 49: 543-68. [CrossRef]

Kwon, Jaok, Markus Pohlmann, and Jivanta Schöttli. 2019. Transnational corporate elites in Japan: International career mobility in East and South Asia. International Journal of Japanese Sociology 27: 1-16. [CrossRef]

Leach, Whitney. 2018. This is where people work the longest hours. World Economic Forum, January 16.

Lee, Jeong-hee. 2003. Hunyuktoenŭn mom, chŏhanghanŭn mom (Trained bodies and resistant bodies). P'eminisŭt'ŭ yŏn'gu (Feminism Research) 3: 157-81.

Lee, Jinyoung, and Jane L. Parpart. 2018. Constructing gender identity through masculinity in CSR reports: The South Korean case. Business Ethics: A European Review 27: 309-23. [CrossRef]

Lee, Yoonkyung. 2011. Militants or Partisans: Labor Unions and Democratic Politics in Korea and Taiwan. Stanford: Stanford University Press.

Lim, Hyun-Chin, and Jin-Ho Jang. 2006. Neo-liberalism in post-crisis South Korea: Social conditions and outcomes. Journal of Contemporary Asia 36: 442-63. [CrossRef]

Mahoney, James. 2000. Path dependence in historical sociology. Theory and Society 29: 507-48. [CrossRef]

Mac an Ghaill, Máirtin, and Chris Haywood. 2007. Gender, Culture and Society: Contemporary Femininities and Masculinities. Basingstoke: Palgrave Macmillan.

Ministry of Gender Equality and Family. 2018. The Ratio of Female Managers in Top 500 Enterprises in South Korea. Available online: http://www.mogef.go.kr/nw/enw/nw_enw_s001d.do?mid=mda700\&bbtSn=706731 (accessed on 14 August 2019).

Ministry of Trade, Industry and Economy. 2015. Monozukuri Hakusho; (Whitepaper on the Manufacturing Industry). Tokyo: Ministry of Trade, Industry and Economy.

Moon, Seungsook. 2005a. Militarized Modernity and Gendered Citizenship in South Korea. Durham: Duke University Press.

Moon, Seungsook. 2005b. Trouble with conscription, entertaining soldiers: Popular culture and the politics of militarized masculinity in South Korea. Men and Masculinities 8: 64-92. [CrossRef]

Nemoto, Kumiko. 2016. Too Few Women at the Top: The Persistence of Inequality in Japan. Ithaca: Cornell University Press.

Nukaga, Misako. 2012. Planning for a successful return home: Transnational habitus and education strategies among Japanese expatriate mothers in Los Angeles. International Sociology 28: 66-83. [CrossRef]

Park, Hyun-sung. 2016. Korea's next big manufacturing leap: Innovation based on culture, creative workforce, and technology. Asian Steel Watch 1: 72-77. 
Park, Juyeon. 2018. Public fathering, private mothering: Gendered transnational parenting and class reproduction among elite Korean students. Gender \& Society 32: 563-86. [CrossRef]

Park, Ju-Young. 2018. Bank under fire for giving oral contraceptive to new female employees. The Korea Herald, January 9.

Pierson, Paul. 2000. Increasing returns, path dependence, and the study of politics. The American Political Science Review 94: 251-67. [CrossRef]

Pocock, Barbara. 1997. Gender and Australian industrial relations theory and research practice. Labour and Industry 8: 1-19. [CrossRef]

Redding, S. Gordon. 1990. The Spirit of Chinese Capitalism. Berlin: de Gruyter.

Reid, Erin M., Olivia Amanda O'Neill, and Mary Blair-Loy. 2018. Masculinity in male-dominated occupations: How teams, time and tasks shape masculinity contests. Journal of Social Issues 74: 579-606. [CrossRef]

Robinson, William I., and Jerry Harris. 2000. Towards a global ruling class? Globalization and the transnational capitalist class. Science and Society 64: 11-54.

Roberson, James. 2005. Fight!! Ippatsu!! “Genki” energy drinks and the marketing of masculine ideology in Japan. Men and Masculinities 7: 365-84. [CrossRef]

Roper, Michael. 1991. Yesterday's model: Product fetishism and the British company man, 1945-1985. In Manful Assertions: Masculinities in Britain Since 1800. Edited by Michael Roper and John Tosh. London: Routledge, pp. 190-211.

Sklair, Leslie. 2001. The Transnational Capitalist Class. Oxford: Blackwell.

Song, Changzoo. 2003. Business elite and the construction of national identity in Korea. Acta Koreana 6: 55-86.

Song, Jiyeoun. 2014. Inequality in the Workplace: Labor Market Reform in Japan and Korea. Ithaca: Cornell University Press.

Suzuki, Nobue. 2007. Marrying a Marilyn of the tropics: Manhood and nationhood in Filipina-Japanese marriages. Anthropological Quarterly 80: 427-54. [CrossRef]

Taga, Futoshi. 2005. East Asian masculinities. In Handbook of Studies on Men and Masculinities. Edited by Michael Kimmel, Jeff Hearn and Robert W. Connell. Thousand Oaks: Sage Publications, pp. 129-40.

Wade, Robert. 1990. Governing the Market: Economic Theory and the Role of Government in East Asian Industrialization. Princeton: Princeton University Press.

Wang, Hong-zen. 2005. Asian transnational corporations and labor rights: Vietnamese trade unions in Taiwan-invested companies. Journal of Business Ethics 56: 43-53. [CrossRef]

Weber, Max. 1989. Gesammelte Aufsätze zur Religionssoziologie I (Collected Essays on the Sociology of Religion I). Tübingen: Mohr.

Whitehead, Stephen M. 2002. Men and Masculinities: Key Themes and New Directions. Cambridge: Polity.

Whyte, William H. 1959. The Organization Man. London: Cape.

Yeoh, Brenda. S. A., Shirlena Huang, and Theodora Lam. 2005. Transnationalization the "Asian" family: Imaginaries, intimacies, and strategic intents. Global Networks 5: 307-15. [CrossRef]

(C) 2019 by the author. Licensee MDPI, Basel, Switzerland. This article is an open access article distributed under the terms and conditions of the Creative Commons Attribution (CC BY) license (http://creativecommons.org/licenses/by/4.0/). 